\title{
Trapped between the Dragon and South Asia's big brother: the case of Sri Lanka's "balanced" foreign policy
}

\author{
Shakthi De Silva* \\ Department of International Relations, Faculty of Arts, University of Colombo, Colombo, Sri Lanka.
}

\begin{abstract}
As China's influence in the Indian Ocean Region grows in preponderance, Indian anxieties have concomitantly intensified. Faced with finite choices as an island in the Indian Ocean, it is intrinsically in Sri Lanka's interest to balance both powers. This study examines the escalating strategic competition between India and China in Sri Lanka and unpacks the contours of their activities and their linkages with the island. It assesses the dexterity of the Sirisena administration to actualize a balanced foreign policy in contrast to its predecessor and outlines a policy formulation which would support the government in its endeavor. The article also contributes to the foreign policy strategising literature by configuring four conceivable external dynamics Sri Lanka may face in future.
\end{abstract}

Keywords: Balanced foreign policy, China, India, Sri Lanka, South Asia, strategic competition.

\section{INTRODUCTION}

Maithripala Sirisena's rise to the position of Executive President of the Democratic Socialist Republic of Sri Lanka in 2015 symbolised a watershed moment. Ensuing a ten year period under the rule of former President Mahinda Rajapakse, the advent of the incumbent 'common candidate' Sirisena demonstrated the impermanence of a repressive stranglehold on the populace (Smith, 2015). 2009 ended for President Rajapakse on a high note. Sri Lankan Armed Forces routed L. T. T. E. separatists in the North-East of the island and despite excessive Government spending on defense (Colombo Telegraph, 2014), a sizeable portion of the public was firmly behind the military offensive. Pressure from the West, however, was mounting.
Rajapakse was progressively alienated on the international stage, most notably, in the 2013 Commonwealth Heads of Government Meeting in Colombo which the Prime Ministers of Canada, India and Mauritius boycotted. Repeated United Nations Human Rights Council's (UNHRC) resolutions called on the Rajapakse Government to investigate allegations of human rights violations and initiate a credible reconciliation mechanism. The West also cut off aid and assistance to the island, including GSP+ facilities Sri Lanka had hitherto enjoyed from the European Union. Allegations of Human Rights violations continued to be brushed aside by Rajapakse, as an indication of foreign interference. At the time, atrocities purported to have been committed during the final phase of the military campaign was not the only charge leveled against the Rajapakse regime. The wave of repression directed at political opponents, the lack of willingness to reach out to the Sri Lankan Tamil minority coupled with alleged support to extremist nationalist groups operating in the island were other reasons for Western political pressure (Sunil \& Vasantha, 2013). Continuously harangued in the Human Rights Council and in multi-lateral diplomatic forums, even South Asia's 'big brother'- India- openly critiqued Rajapakse's domestic policies (Rizvi, 2015).

Given Rajapakse's overwhelming reliance on China, manifestly displayed by the loans the island obtained from Beijing (Colombage, 2014), and his growing estrangement with India and the West, what did the Sirisena administration choose to do once elected? In

"Corresponding author (shakthi721994@gmail.com; (D https://orcid.org/0000-0001-8645-3729) 
spite of being critical during the campaigning season on the Sino-Sri Lankan ties under Rajapakse, Sri Lanka did not execute a U-turn in its relations with China under President Sirisena. Indeed, at a time when some policymakers openly advocated for this move, (buoyed by Sirisena's desire to stop Chinese projects which he termed as being settled by the previous government on onerous terms), scholars argued against such hasty actions. Given the academic and political consensus on the need for a 'balanced' foreign policy, this paper questions the possibilities and likelihood of President Maithripala Sirisena sustaining a 'balanced foreign policy' with India and China.

Why must a balance of this nature be established? What is the impetus or rationale behind its necessity? What are the ramifications of flaunting the security concerns of India by being enmeshed with China as Rajapakse had done? Regardless of the personal motives behind Rajapakse's actions, one cannot deny that his justification has some veracity. China is the region's biggest investor and with such 'deep pockets' it was undeniably in the interests of Sri Lanka to form a robust relationship with China. However, turning a blind eye to India had undesirable consequences for the Rajapakse regime. As suggested by the former President in 2015, India had operated with "domestic opposition leaders" in the country during his tenure (as quoted in Indiatoday, 2015). New Delhi also helped sustain international pressure on the human rights and reconciliation front against Sri Lanka. Together, this formed a potent force supporting the eventual toppling of the Rajapakse regime.

Conversely, what are the consequences of being ProIndian at the expense of preserving amicable ties with China? Naturally, a loss of potential Chinese investment and loans would ensue, dampening the island's prospects for development. As a result, it is imperative that Sri Lanka manage the interests- both security and economic- of India and China, if it wishes to pursue its economic vision as an Indian Ocean Hub free from negative external interference and intervention. It is the hypothesis of this paper that the cost of disregarding this is too high. In the $21^{\text {st }}$ century context, balancing the two rapidly surging powers of Asia- China and India- whilst obtaining the best from both is plainly of quintessential need for the island.

This paper begins by gauging Sri Lanka's foreign policy under President Sirisena in conjunction with the constraints faced by the leadership in charting its foreign policy. During the 2015 presidential campaign, Maithripala Sirisena expressed his desire to inaugurate a balanced foreign policy in contrast to his predecessor Mahinda Rajapakse. His manifesto in effect declared that "equal relations" will be adopted with China and India during his administration (Sirisena, 2015b). Although Sirisena's political opponents claimed that his foreign policy would be anti-Chinese and pro-Indian in outlook as Sirisena was determined to revamp the fraught Indo-Lanka ties under former President Rajapakse- the incumbent President appeared to covet an "attitude that would be neither anti-Indian nor dependent" on New Delhi (Sirisena, 2015b: p. 44).

In an interview to the Hindustan Times, Prime Minister Wickremesinghe declared, "We will improve relations with India. However, that doesn't mean we will be hostile to China" (as quoted in Sundarji, 2015). A former Sri Lankan economic affairs spokesperson, Harsha De Silva, also went on record stating that the new Government intends to have,

"a balanced approach between India and China, unlike the (previous) regime, which was antagonizing India almost by its closeness to China" (as quoted in Ellen, 2015).

Nevertheless, domestic pressures including Sri Lanka's debt burden as well as international disagreements and tensions between India and China makes the task of maintaining a balance more difficult. This is particularly felt today, as Sri Lanka features squarely in China's Belt and Road Initiative (BRI). Thus, a policy dilemma materialises when one considers the likelihood and ability of Sirisena to maintain a balanced foreign policy towards China and India, especially given how both New Delhi and Beijing increasingly view the island in geo strategic terms and are keen to wean away the island from their rival.

\section{LITERATURE REVIEW: AN AFFIDAVIT OF PRESIDENT SIRISENA'S ‘BALANCING’?}

In order to explore the paper's research question, a holistic examination of the existing literature is required. Firstly, it is essential to engage with the scarce but budding literature on the foreign policy of the present Sri Lankan government. Because the National Unity Government is yet to finish its first term in office, no major books, taking into account President Sirisena's foreign policy, have been completed. Literary analysis and contextual survey on this period therefore, remain locked to journal articles, conference proceedings, academic blogs and academic commentaries. This study principally utilizes and engages with this body of work.

While some scholars and policy makers (including the President himself) argue that the present administration follows a "friendship with all foreign policy" 
(Karunanayake, 2017; Ockersz, 2017; Sirisena, 2015a; 2016), others stress that the present leadership wishes to maintain an Asia centric middle path (Senadhira, 2017). Commenting on the island's external relations, Uyangoda claims that,

"avoiding an ideological identity in its foreign policy strategies seems to be a key defining feature of the Maithripala Sirisena-Ranil Wikremasinghe administration" (Uyangoda, 2016).

Panditaratne asserts that,

"Sri Lanka aims to forge a dual identity, as the centre of the Indian Ocean and an economic entry point to the Indian subcontinent" (Panditaratne, 2017).

These views tie into the former Foreign Minister's statement of making Sri Lanka an 'Indian Ocean Hub' (Samaraweera, 2017). Notwithstanding different lexicon used to distinguish the island's foreign policy, one major takeaway is that it overwhelmingly points to Sri Lanka's efforts at forging ties with both China and India.

Without doubt Sri Lanka has balanced against (De Silva, 2015; August 2017; October 2017) and aligned with stronger adversarial great powers in the past (Gamage, 2017). As the prevailing international system is in a state of flux, the rising power potential and strategic interests of China and India make the task of charting Sri Lanka's foreign policy formidable. For example, citing Central Bank reports, Moramudali exposes how Sri Lanka's external debt stock was only US $\$ 10.6$ billion in 2006 , but,

\footnotetext{
"by the end of 2016, Sri Lanka's external debt stock soared to US \$ 25.3 billion, which amounts to 34 percent of the country's gross domestic product. Out of this massive debt stock, about 13 percent...is owed to China; most of the debt to China was obtained over the last decade" (Moramudali, 2017).
}

Circumscribed by this debt, it is undoubtedly in the island's interest to elevate political ties with China and resolve any points of conflict. Both the historical affinity between the two since the 1952 Rubber-Rice Agreement and China's material and moral support offered to Sri Lanka during the final stages of the ethnic conflict as well as in the post-conflict reconstruction phase cannot be discounted.

On the other hand, Maithripala Sirisena took note of the Indo-Sri Lanka relations under former President Rajapakse and claimed that,
"Our (government's) Indian policy will take into due consideration the diversity of India. I would act to have closer relations with an attitude that would be neither anti-Indian nor dependent" (Sirisena, 2015b: 44).

While downplaying Indian concerns over Chinese infrastructure investment in Colombo and Hambantota, Prime Minister Wickremesinghe urged New Delhi to invest more in the island, even in projects that are being financed by Beijing. In this respect, Sri Lanka's interest to jointly develop the Trincomalee Port with Japanese and Indian investments could be viewed as demonstrative of a desire to adopt a centrist position towards India and China (Shimbun, 2018).

Thus, the research question which this study intends to unpack begins to emerge. Hitherto, the government has come across as eager to forge ties with both New Delhi and Beijing but, given the diverse strategic intentions of Asia's powerhouses and the island's own domestic concerns, can Sri Lanka effectively balance the two countries in future?

Finally, this study also requires theoretical insights from International Relations scholars as a basis to explore the research question in-depth. Utilizing Keohane \& Nye's Theory of Complex Interdependence (2012), the paper substantiates the view that the foreign policy agenda of the island has moved on from a concentration on 'security' in the traditional Realist template. In this paper Complex Interdependence refers to a situation where,

"multiple channels of contact connect societies (that is, states do not monopolize these contacts); there is no hierarchy of issues; military force is not used by governments toward one another" (Keohane \& Nye, 2012: p. 265).

By applying this theory, the author simultaneously examines Sri Lanka's economic and military channels of contact with India and China without acceding to a military dominated foreign policy agenda or a traditional security led hierarchy of issues between the states. Although Complex Interdependence could also be used to characterise the bilateral ties between India and China, this study does not examine this sphere. What needs to be emphasised at this point is that, even as the growing importance of economic, environmental and social aspects of the Indo-China bilateral relationship symbolises a Complex Interdependence, it does not necessarily entail a diminution of their strategic competition. 
Also important to note is that the paper does not apply 'balancing' in a Realist sense of the term. Neo Realists such as Walt defines balancing as "allying with others against a prevailing threat" (Walt, 1990: p. 108). Neo Realists argue that States balance against a threatening power by aligning with another regional power(s) or with an extra regional power(s). Waltz (2000: p. 38) notes that in essence, "balancing is a strategy for survival". A foreign policy based on balancing requires the creation of a coalition/alignment of state(s) that could subdue the aggressive behavior of the incipient hegemon. In this study, however, balancing is used to connote the meaning: 'balanced'. In other words, a foreign policy which is unprejudiced and even handed to both powers. A balanced foreign policy in this regard, would necessitate friendly relations with China and India without inclining towards or being partial towards one over the other. As a result, there is no threatening power in a military sense as argued in conventional balancing literature, rather a desire to maintain an unequivocal equilibrium between China and India which would serve the functional interests of the island.

\section{CHINA AND INDIA: CAUGHT UP IN THE STRATEGIC DEBATE}

"It is for the people of Asia to run the affairs of Asia, solve the problems of Asia, and uphold the security of Asia", President Xi remarked at the fourth Conference on Interaction and Confidence-Building Measures in Asia Summit (CICA) in May 2014 (as cited in Oba, 2016: p. 106). Xi's edict later came to be referred to as the 'New Asian Security Concept'. Instantaneously, queries arose in Indian policy circles about the odds of China becoming either a revisionist power or a State that can live in co-existence with a rising India. Over the years, the Regional Comprehensive Economic Partnership (RCEP), BRICS (an acronym coined for an association of five major emerging economies: Brazil, Russia, India, China and South Africa), Belt and Road Initiative (BRI), Asian Infrastructure Investment Bank (AIIB) and the Shanghai Cooperation Organization (SCO) demonstrated China's desire to exert its leadership. While grouping all of these initiatives (some solely directed by Beijing and others not) may not do justice in deciphering the exact degree to which China played a role in their formulation, it cannot be ignored that devoid of Beijing, most if not all these initiatives may not have reached fruition today. To quote Lukonin, "Chinese diplomacy is no longer peripheral, but instead global” (Lukonin, 2017: p. 4). From 2012 to 2017, Xi hosted 5 of the world's major summit meetings including the Asia-Pacific Economic Cooperation (APEC) in 2014, G20 in 2016 and the
BRICS in 2017. Jian \& Xiaoqin (2015) view the zenith of China's projects, the Belt and Road Initiative, as setting a new international order, becoming a model for regional cooperation and international economic cooperation. Without doubt this may redefine the China-India nexus notwithstanding India's refusal to be part of the BRI.

Even as some hypothesize that Chinese leaders desire multipolarity and resent unipolarity (Cheng, 2016), others point to a different frame of reference. They advance the view that China will seek to replace or restructure America's benign unipolarity with a World Order of its own. Either way, both moves involve a re-orientation of the present security and economic architecture. This begs the question, what does China desire from these initiatives? Beckley argues that,

"it is the power to set agendas, to shape the normative frameworks within which states relate to one another and to change the range of choices open to others without putting pressure directly on them" (Beckley, 2011/12: p. 48).

If this is the case, it increases the complexity and difficulty of mollifying fears of a "Chinese Threat". This is especially so in the case of India.

The most important security mechanism in the Asia-Pacific region, i. e. the Hub-and-spokes bilateral security system of America, beheld Chinese inroads into America's traditional allies. Pollack observes that,

"China is the only regional power with meaningful security involvement in the four principal subregions of Asia and the Pacific (North East Asia, South East Asia, South Asia and Central Asia)" (Pollack, 2005: p. 330).

Beijing has molded ties with South Asian countries through the often touted 'String of Pearls' strategy as well as through investments and bountiful sums of loans. Although former Premier Wen Jiabao iterated: "There is enough space in the world for the development of both China and India" (as quoted in Wee \& Neogy, 2010), Khanwal opines a commonly held Indian view that Chinese activities,

"clearly indicate that concerted efforts are underway aimed at the strategic encirclement of India...Quite obviously designed to marginalise India in the long-term and reduce India to the status of a sub-regional power...It [China] is unlikely to tolerate India's aspirations to become a major regional power in the Asia-Pacific region" (as cited in Lone, 2017: p. 129). 
Taking stock of China's activities allows one to discern the shifting balance of power in South Asia. Balance of power literature introduces two main ways in which it can be challenged. On the one hand, if a major power augments its strength to a point where it threatens to achieve hegemony, then the balance of power logically shifts to disequilibrium. Similarly, a balance of power is also challenged when a hitherto secondary State contests the existing status quo as it tries to enter the rank of the major powers; initiating a series of compensating adjustments by the other powers until a new equilibrium is established (Kissinger, 2015). China's rise evidently relates to the first scenario. As China's power and influence grows across India's neighbors, New Delhi views this with undisguised apprehension and has scrambled to build closer ties with USA and Japan (Samaranayake, 2012). Indian fears are best expressed by Singh who concludes that,

"a sustained maritime presence in the Indian Ocean Region will not only allow Beijing to strategically dominate the region, it will also take the regional security initiative away from India" (Singh, 2015: p. 297).

Pattanaik believes that,

"China's increased engagement with the countries of South Asia has two important components... First, to counter balance India; and second, to gain strategic space in the Indian Ocean" (Pattanaik, 2016: p. 133).

Recent evidence appears to corroborate this view. Between 2005 and 2013, Chinese assistance to Sri Lanka amounted to "US \$ 5.664 billion, out of which 98 per cent was in the form of loans" (Sultana, 2016: p. 246). This prompted Sri Lanka, an island lying in the epicenter of the arc connecting the Persian Gulf to the Strait of Malacca, to elevate her ties with China to a "strategic cooperative partnership" in 2013 (Ayres \& Anderson, 2015). In Bangladesh,

"Chinese firms have invested heavily in power and infrastructure projects such as in the development of Chittagong harbour and in road links to improve connectivity" (Wagner, 2016: p. 313).

In 2015, China and Pakistan launched the China Pakistan Economic Corridor (CPEC), one of the largest projects in South Asia, costing close to US \$ 46 billion. This initiative combined with others persuaded Pakistan to characterize her ties with China with phrases such as "iron-brother relationship" and "all-weather friends".
However, over the last few years, tensions between India and China have been simmering.

"Beijing barred New Delhi from becoming a member of the Nuclear Suppliers Group (NSG), blocked India's attempts to list Masood Azhar, as a terrorist at the United Nations and even routed its energy pipelines through disputed territory in Kashmir showcasing scant regard to India's calls for the pipelines to be re-routed" (De Silva, 2018).

A recent Pew Research captured this bubbling tension rather lucidly. According to the survey, India's public perception of China had declined from a 35\% favorable outlook in 2013 to just $26 \%$ by 2017 (as cited in China Power, 2017).

Frictions also persist along disputed portions of the Sino-Indian border, where both countries patrol with armed forces. The recently concluded Doklam crisis is the latest episode on this front. A report by the Secretary of Defense to the U. S. Congress noted that,

"Tensions remain with India along the shared 4,057 km border over Arunachal Pradesh, which China asserts is part of Tibet and therefore part of China and over the Aksai Chin region at the western end of the Tibetan Plateau, despite growing China-India political and economic relations. China and India continue to accuse each other of frequent incursions and military buildups along the disputed territories" (Department of Defence U.S., 2017: p. 41).

A case in point is a Huanqiu commentary on July 28, 2017 which,

"warned India not to mess with [Beijing because]: China has the capacity to make each of India's northeastern states independent" (as cited in Malik, 2017).

India has begun to match the efforts of China's peripheral and extra regional diplomacy. Indeed in recent years New Delhi has demonstrated an enterprising streak in its foreign policy strategies. Exhibiting marked interest to bolster ties with neighboring countries, India launched the Look East-Act East, Connect Central Asia and the Neighborhood First foreign policy. However, given the timing of these strategies, they can be viewed as a reaction to China's decisive moves into South Asia and India's northern neighborhood. What of Sri Lanka, the case study of this paper? How has the Sino-Indian strategic competition manifested itself in this pearl shaped island $32 \mathrm{~km}$ off the coast of India? 
Before tackling this question one needs to recognize that the strategic competition between India and China as outlined above, does not amount to an inevitable clash. Indeed, the possibility of a border dispute manifesting into a larger conflict narrative is inconceivable. China is India's largest trading partner with two-way trade totaling approximately US \$ 65.5 billion in 2013 (Vandewalle, 2016: p. 6). Additionally, cooperation through the BRICS and SCO as well as joint operations by the forces of both countries and bilateral meetings serve to decrease tensions between the two civilizational States. Be that as it may, their strategic competition has not diminished by these actions. Sri Lanka is a case in point.

\section{EQUIDISTANT BALANCING?: THE PROSPECTS OF A TROUBLED ISLAND}

"Historically, China and India each had its own geographic orientation: China toward East Asia and India toward South Asia" (Wang, 2011: p. 450).

This has led to the belief that China concedes South Asia and the Indian Ocean Region as India's sphere of influence. However, is this the case today? $\mathrm{Su} \mathrm{Ge}$, the President of the China Institute of International Studies, termed Sri Lanka and China as "neighbors" in his opening remarks at the Bandaranaike Centre for International Studies' Seminar on Contemporary China (Ge, 2017: p. 4). Indeed, Sri Lanka was said to occupy an important position in China's "neighborhood diplomacy" (Ge, 2017: p. 5), although the island is located some $3,900 \mathrm{~km}$ away from mainland China.

During the Rajapakse tenure, Chinese support did not limit itself to loans and developmental aid. Jayewardena affirms the support given by China in the United Nations Security Council by barring the island's deteriorating security condition from being deliberated in the Security Council (Jayewardena 2017: p. 15).

"In international relations and global politics, the OBOR, AIIB, and SCO all of which include Sri Lanka provide for deeper engagement, increased opportunity and strengthened connectivity with Beijing" (Cooke, 2017: p. 25).

President $\mathrm{Xi}$ previously visited the island and Chinese investment dot the islands coastline.

"From 2005 to 2014, China spent US \$ 870.4 billion in worldwide investments and contracts, out of which US \$ 8.9 billion was invested in Sri Lanka. In Sri Lanka, China is the biggest source of Foreign Direct Investment (FDI), pumping in more than US \$ 400 million in 2014" (Kahandawaarachchi, 2017).

During the Rajapakse era, China was involved in a variety of projects such as the Norochcholai Coal Power Plant, Mattala International Airport, Katunayake Airport Expressway, the Southern Expressway, Hambantota Port, the Lotus Pond (Nelum Pokuna) Performing Arts Theatre and the expansion of the Colombo Port.

While the bewildering- but not exhaustive- array of projects listed above demonstrates a growing amity between China and Sri Lanka, the island's debt ratio did not paint a rosy picture. By the end of Rajapakse's tenure, $90.6 \%$ of the Government total revenue was spent for debt servicing (Wickremesinghe, 2017: p. 2). Non-concessional and commercial components of the government foreign debt had risen from $1 \%$ in 2000 to 53\% in 2016 (World Bank, 2017: p. 39). The Vision 2025, blueprint published by the Prime Minister's Office, indicates Sri Lanka's public debt as reaching 79.3\% of GDP (Prime Minister's Office, 2017: p. 17). Sri Lanka’s "total outstanding external debt was US \$ 25.61 billion in April 2017 ....Chinese loans accounted for over US \$ 8 billion of this amount..." (Mitra, 2017). Turning away from China is no longer an option even if the political echelons desire it. Consequently, Sri Lanka has to maintain amicable ties to China. While the gradation may not have to resemble the Rajapakse era; indubitably, Sri Lanka will desire a continuation of constructive engagement with Beijing.

Indo-Sri Lanka ties were on a firm footing from President Sirisena's inception. Historically, ties between the Sri Lanka Freedom Party (headed by President Sirisena) and India have always been strong. This relationship began under S. W. R. D Bandaranaike and Nehru, and blossomed under Sirimavo Bandaranaike and Indira Gandhi. A continuation of this was patent during the 2015-2017 period. For example, from 2008 to 2017, 361 warships entered the Colombo Port. While 26 of them were from China, India docked close to three times that figure (Colombage, 2017: p. 41). Addressing a gathering at the Lakshman Kadirgamar Institute of International Relations and Strategic Studies on November $20^{\text {th }} 2017$, Dr S. Narayan- the former Finance and Economics Minister of India- acknowledged the US \$ 4.7 billion bilateral trade balance between the two countries as emblematic of a close economic relationship. Whilst he agreed that China outclasses India in commercial investments, he declared that soft assistance from India (aid and grants) to Sri Lanka exceeds that of China by a great margin (Narayan, 2017). Prime Minster Wikremasinghe's desire to conclude the Economic and Technology Co-operation Agreement (ETCA) with India 
and link India to the Trincomalee harbor is also reflective of Sri Lanka's posture of expanding ties with South Asia's big brother. Reports suggest that the Mattala International Airport, despite incurring losses to the tune of US \$ 112.9 million, is also being considered by the Indian government to be managed as a joint venture with Sri Lanka (Wijeyarathna, 2017). Moreover, the personal rapport between Modi and Sirisena has continued to reach new heights in the past years following numerous bilateral summit meetings between the two.

India continues to hold onto South Asia as its 'backyard' and increasing Chinese influence in the region is viewed with apprehension and acrimonious distaste. India believes that if Beijing was to follow a hexiao gongda policy in South Asia- uniting with the small (Pakistan, Bangladesh, Burma, Nepal and Sri Lanka) to counter the big (India)- India must coalesce its neighbors into a tighter union with itself (Malik, 2009: p. 1145). This strategic friendship could be underlined by military, economic and social linkages. As a result of this milieu, charting a foreign policy becomes complex and challenging. Balancing the security and economic interests of Sri Lanka's closer geographical neighbor and the world's rising 'Far-East' civilizational state is by no means an easy task. How has Sirisena managed in the three years he has been in power?

\section{BALANCING CHINA AND INDIA: A BRIEF RETROSPECTIVE OF THE RAJAPAKSE AND SIRISENA PRESIDENTIAL TERMS}

As discussed above, leaning to one side over the other is no longer a viable option for Sri Lanka. For years the island went through an ethnic conflict involving separatist militants against the Sri Lankan government. Once the war was over in 2009, President Rajapakse outlined his blueprints for economic growth. However, investments from western capitals were not forthcoming in the expected volume. Growing corruption and wasteful expenditure in conjunction with the clarion call from the West and India for reconciliation and truth seeking pushed him towards China. Added to this was the lack of a long term strategy under the Rajapakse administration. This was accentuated by Grace Asirwatham, the Sri Lankan State Secretary to the Ministry of Foreign Affairs, at a guest lecture at the University of Colombo on $08^{\text {th }}$ November 2017. Juxtaposing the Sirisena regime to the Rajapakse regime she conceded that the latter administration had its "own way of doing foreign policy...Foreign policy was then conducted by a small circle of people". Brewster maintains that:

"Rajapaksa not only seemed to favour Chinese investments but he also began to flirt with a limited Chinese security presence on the island.
New Chinese-built ports at Hambantota and Colombo became symbols of Beijing's presence in the region, fuelling claims of a 'String of Pearls' across the Indian Ocean... The turning point came in September 2014 when a Chinese submarine and minder made an unexpected visit to Colombo only days before the visit of Chinese President $\mathrm{Xi}$ Jinping to New Delhi” (Brewster, 2015).

Gotabhaya Rajapakse (the brother of former president Mahinda Rajapakse and Sri Lanka's former Secretary to the Ministry of Defense) arguably played a pivotal role in Sri Lanka's foreign policy formulation. His article to a journal of the U. S. Department of Defense in 2014 reads: "It is essential to continue to strengthen the existing cordial relationships with powerful nations such as China" (Rajapaksha, 2014: p. 155). This strengthening was visible from 2003 to 2016 as Chinese vessels and submarines boasted 9 overall port calls and 3 military exercises with Sri Lanka (Allen et al., 2017: pp. 53-62). High level bilateral meetings between Sri Lanka and China reached a high number of 27 from 2005-2015 under the Rajapakse administration.

As the literature review uncovered, Sri Lankan scholars and policy makers favored a balanced foreign policy for the island in the post Rajapakse era. However, have policy makers effectively balanced between and accommodated the two rising powers? In late July 2017, the Sirisena government agreed to give China control of the Hambantota port- a 70 percent equity stake over 99 years- in exchange for writing off US $\$ 1.1$ billion of the island's debt. On May $16^{\text {th }}$, Reuters noted that the,

"Sri Lankan Prime Minister Ranil
Wickremesinghe told Chinese President Xi
Jinping that he welcomed increased Chinese
investment in Sri Lanka's major infrastructure
projects" (Reuters, 2017).

Sri Lankan leaders have been warmly welcomed in Beijing and ties between the two governments appear to be resilient. However, unlike Rajapakse, deference is also given to India's security concerns. This was clearly exhibited when a Chinese submarine was refused to dock in the Colombo Port in 2017; in contrast to the 2014 decision of allowing a Chinese nuclear submarine to dock in the same port. As Goldstein discerned,

"the docking of Chinese submarines in Sri Lanka during September and November 2014 (had) caused a stir in Indian national security circles" (Goldstein, 2015: p. 306).

This policy was expeditiously discontinued by the present regime. 
India has, by and large, been seen by the new government as a power Sri Lanka must engage with and accommodate. For example, Tilak Marapana who assumed duties as the Minister of Foreign Affairs on the $18^{\text {th }}$ of August 2017, met with the High Commissioner of India H. E. Taranjit Singh Sandhu just four days later. 18 days later he called on Prime Minister Narendra Modi in India (Ministry of Foreign Affairs, 2017). The Hatton Dickoya Base Hospital, which was built on a Rs. 1,200 million fund from the Indian government, was vested with the public by the Indian Prime Minister Narendra Modi who arrived on the invitation of President Sirisena for the Annual Vesak Celebrations (Mendis, 2017). For the most part, the personal rapport between the two leaders has been strong and this relationship was further augmented after India expressed its desire to sign the Economic and Technology Cooperation Agreement (ETCA) as well as jointly conduct operations in the loss making Mattala International Airport.

An article posted in the National Unity Government's Ministry of Defense website aptly sums up the reinvigorated ties between India and Sri Lanka. Describing a visit by the Indian Foreign Minister to Sri Lanka in 2016, the website quotes both the Sri Lankan President and Indian Foreign Minister, Mrs. Sushma Swaraj, in the following manner: "India has been a friend of Sri Lanka for a long time. That is why I selected India for the first state visit after my election as the President", said President Sirisena (Ministry of Defense, 2016). Responding to the President, the Indian Foreign Minister stated that India's policy is to keep close friendships with the neighboring countries: "The Indian government gives priority to Sri Lanka in this regard" (Swaraj, S., as quoted in Ministry of Defense, 2016).

In essence, not only has Sri Lanka endeavored to forge stronger ties with both countries but a balance between India and China is also manifest. By welcoming both powers to invest and trade with the island, the political administration hopes that Sri Lanka's economy would grow alongside theirs, so that the Government's vision to make Sri Lanka into an 'Indian Ocean Hub' and link up with global production networks reaches fruition (De Silva, 2018). The longevity of the island's balanced foreign policy depends on Sri Lanka's bilateral relations with India and China, the bilateral ties between $\mathrm{Xi}$ and Modi, as well as the Sri Lankan Government's ability to take into account and accommodate the concerns and strategic interests of both China and India in a manner that does not jeopardize the interests of Sri Lanka.

SRI LANKA'S BALANCED FOREIGN POLICY: THE LIKELIHOOD OF ITS FUTURE?

Menon opens his book Choices by reflecting on the difficulty involved in foreign policy decision making. To give a flavor of his argument, the author can do no better than to quote directly from Choices:

"All governments claim eternal consistency and success. Some even claim omniscience. And yet the essence of governance is choice. Choice involves uncertainty, risk and immediacy; those who must make the choices operate in the contemporary fog that envelopes events rather than from the certainty and clarity that comes with time, distance and reflection. Nowhere is this more true than in foreign policy decision making" (Menon, 2016: p. 1).

Given how,

1. Sri Lanka expressively stated and in praxis operated (from 2015 to mid-2018) a balanced foreign policy towards China and India and

2. the degree to which Sri Lanka requires the economic and political support of India and China for its development,

it can be speculated that the most likely challenge to the continuance of this balanced policy stance resides in the external arena. The author is, therefore, able to trace four main scenarios the island may face in future; three of which are direct impediments to the continuance of a balanced foreign policy:

1. China leveraging its economic influence to push Sri Lanka away from developing ties with India.

2. Indian political interference directing Sri Lanka away from China.

3. Relations between China and India deteriorating to the point of hostility, forcing Sri Lanka to choose a side.

4. Reasonably cordial relations between the two Asian Giants enabling Sri Lanka to balance India and China with due consideration of the island's own economic and security interests.

Hitherto under the Sirisena administration, Sri Lanka was able to operationalize a centrist foreign policy stratagem due to comparatively minor tensions and disagreements between India and China. However, New Delhi and Beijing are increasingly flexing their muscles in the international arena and the former views the latter's rise with great distrust. Although both governments are working to iron out their individual differences, rapidly expanding Chinese interest and activities in the Indian Ocean Region has and will continue to spark Indian apprehensions. Caught between the strategic interests of both states, Sri Lanka has to cultivate foreign policy 
coherence and a long term strategy (S. Dias 2017, Interview, $21^{\text {st }}$ October). Henceforth, the Sirisena administration must analyze and explore the varied implications and possible issues or causes of conflict that may arise in Sri Lanka's relationship with India and China as well as between the great powers themselves. The cost of turning a blind eye or overlooking the bilateral ties between Modi and Xi is too great to disregard.

Keohane \& Nye (2012) took Complex Interdependence to mean interactions with costly effects. Embedded in this are the concepts of sensitivity and vulnerability.

"Sensitivity refers to the costly effects of crossborder flows on societies and governments, within an unchanged framework of basic policies" (Keohane \& Nye, 2012: p. 232).

"The vulnerability dimension of interdependence rests on the relative availability and costliness of the alternatives that various actors face" (Keohane \& Nye, 2012: p. 11).

Caught between the two Asian Giants, Sri Lanka is significantly sensitive to both the bilateral relationship between China and India, as well as the island's relationship with each power. If scenario 1, 2 or 3 was to take place, the costliness of taking effective adjustments would be significant, possibly even too much to bear.

The island is also dependent on friendly relations with both powers.

"To emphasize this point a simple example suffices. The island's largest portion of FDI in 2017 is from China followed closely by India. Conversely, Chinese tourist arrivals account for $13 \%$ of total tourist arrivals to the island. This is second only to India" (De Silva, 2018).

Thus, the two Asian Giants are essential for Sri Lanka's path to development. Given the degree of dependence and the lack of alternatives to choose from, Sri Lanka is vulnerable to both powers as well.

Based on the complexities involved in navigating between India and China, a multi actor perspective to ensure the long term security and economic interests of the island could be recommended. A multi-actor approach focuses on,

"the legitimacy of multiple actors in a specific context, instead of assuming an all-encompassing legitimacy for one actor in all contexts" (Gjørv, 2012: p. 13).
Such a multi-actor approach would be able to pool together resources in university establishments, nongovernmental agencies as well as other International Relations institutes based in the country such as the Bandaranaike Center for International Studies, Regional Center for Strategic Studies, Institute of National Security Studies of Sri Lanka, Institute of Policy Studies etc. While a multi-actor approach could initially focus on actors in institutions and academia as well as in governmental and non-governmental agencies, further steps can be taken to expand this to a regional basis, if the need arises.

Utilizing a multi-actor approach, foreign policy decision makers are able to better determine the parameters or boundaries of what is, or is not, a part of the security and economic dynamic at a particular time. It also enables decision makers to utilize multi-dimensional perspectives in academic and institutional networks regarding the positive and negative implications and externalities of pursuing a particular course of action. This foresight allows for a better-judged decision which will have greater chances to benefit the country in the short and long term. Thus, a multi-actor approach would be able to holistically analyze and assess all the alternatives, dimensions and implications of a foreign policy decision.

In the event Sri Lanka confronts either option 1, 2 or 3, charting its path between China and India will be precarious. A multi-actor perspective even at a consultative level at the cabinet level or at the foreign ministry level would be able to pool together resources to analyze possible options and implications of following different foreign policy options on a contextual basis. This would enable policy makers to look at a particular issue (such as obtaining a commerical loan to finance an infrastructure project) from different lenses and weigh the costs and benefits from a political, economic and social perspective. Sri Lankan policy makers could also more effectively prioritize viable and beneficial project initiatives and comprehensively scrutinize whether the costs are reasonable compared to the returns on investment.

Through confidential interviews with senior diplomats, the author was made aware of consultations between line ministries and the Foreign Ministry on certain foreign policy matters. The frequency of such consultations has risen over recent years but the degree of consultations with institutions- such as those listed above- is rare. Given the advantages of a multi-actor perspective and the complexity in the trilateral IndiaChina-Sri Lanka nexus, the importance of such an approach has markedly increased. 
By welcoming both powers to invest and trade with the island, the political administration hopes that Sri Lanka's economy would grow alongside theirs so that the Government's vision to make Sri Lanka into an 'Indian Ocean Hub' and link up with global production networks reaches fruition (De Silva, 2017). However, this desire to project Sri Lanka as an 'Indian Ocean Hub' needs to be backed up by political consensus and a bi-partisan and unwavering foreign policy based on enlightened national interest. This is best ensured through a multi-actor foreign policy approach which would provide diverse perspectives and a more holistic understanding of the foreseeable economic and political externalities of pursuing a particular course of action in the foreign policy domain.

\section{REFERENCES}

Allen, K., Phillip S. and John C. (2017) Chinese Military Diplomacy, 2003-2016: Trends and Implications, Washington, D. C: National Defense University Press.

Asirwatham, G. (2017) Sri Lanka's Foreign Policy (Guest Lecture), $08^{\text {th }}$ November, University of Colombo, Sri Lanka.

Ayres, A. and Anderson, A. (2015) Economics of Influence: China and India in South Asia, Council on Foreign Relations. [Online] Available from: https://www.cfr.org/expert-brief/ economics-influence-china-and-india-south-asia [Accessed: $27^{\text {th }}$ February 2017].

Beckley, M. (Winter 2011/12) China's Century? Why America's edge will endure, International Security, 36(3), pp: 41-78.

DOI: https://doi.org/10.1162/ISEC_a_00066

Brewster, D. (2015) Sri Lanka tilts back from China, East Asia Forum [Online] Available from: http://www.eastasiaforum. org/2015/09/17/sri-lankas-tilts-back-from-china/ [Accessed: $24^{\text {th }}$ April 2016].

Cheng, Y. S. (2016) Xi Jinping's 'New Model of Major Power Relationships' for Sino-American Relations, Journal of Comparative Asian Development, 15(2), pp: 226-254.

DOI: https://doi.org/10.1080/15339114.2016.1203342

China Power (2017) How are Global Views on China Trending?, China Power - CSIS [Online] Available from: https://chinapower.csis.org/global-views/ [Accessed: 11 $1^{\text {th }}$ January 2018].

Colombage, D. (2014) Sri Lanka's surging cash reliance on China, Al-Jazeera [Online] Available from: https://www. aljazeera.com/indepth/features/2014/08/sri-lanka-economyreliance-china-infrastructure-20148256345589851.html [Accessed: 23 ${ }^{\text {rd }}$ July 2016].

Colombage, J. (2017) China-South Asia Relations and implications for Sri Lanka, In George I. H. Cooke (Ed)
Contemporary China-Sri Lanka Relations, pp: 40-45, Borella, Sri Lanka: BCIS Press.

Colombo Telegraph (2014) A Record Increase in Sri Lanka's Defence Expenses For 2015, Colombo Telegraph [Online] Available from: https:/www.colombotelegraph.com/index. php/a-record-increase-in-sri-lankas-defence-expensesfor-2015/ [Accessed: $8^{\text {th }}$ September 2017].

Cooke, G. (2017) Chinese Perspectives of China-Sri Lanka relations: Priorities and Trends, In George I. H. Cooke (Ed) Contemporary China-Sri Lanka Relations, pp: 18-26, Borella, Sri Lanka: BCIS Press.

De Silva, S. (August 2017) Regional hegemony and small state survival: re-examining Ceylon's Foreign Policy under Premier D. S. Senanayake, Paper presented at the International Research Conference. General Sir John Kotelawala Defense University Sri Lanka, Rathmalana, Sri Lanka: General Sir John Kotelawala Defense University.

De Silva, S. (October 2017) A strategic foreign policy nexus: The case of Ceylon and the United Kingdom in the backdrop of India's rise, Paper presented at the Bandaranaike Center for International Studies Emerging Scholars Symposium, Borella, Sri Lanka: Bandaranaike Center for International Studies.

De Silva, S. (2018) Will Sri Lanka manage to perform the balancing act between China and India?, South Asia - London School of Economics [Online] Available from: http://blogs.lse. ac.uk/southasia/2018/01/19/will-sri-lanka-manage-to-performthe-balancing-act-between-china-and-India/ [Accessed: 25 $5^{\text {th }}$ June 2018].

De Silva, S. (2015) Balancing, Bandwagoning or Hedging? Independent Ceylon's Reaction to Regional Hegemony, South Asian Survey, 22(2), pp: 189-209.

DOI: https://doi.org/10.1177/0971523117753929

De Silva, S. (2017) Sri Lanka's foreign policy-Security Architecture, Bandaranaike International Diplomatic Training Institute Blog [Online] Available from: http://bidti. blogspot.com/2017/04/sri-lankas-foreign-policy-security.html [Accessed: $8^{\text {th }}$ January 2018].

Department of Defense (2017) Annual Report to Congress: Military and Security Developments Involving the People's Republic of China 2017, U. S Department of Defense [Online] Available from: https://dod.defense.gov/Portals/1/Documents/ pubs/2017_China_Military_Power_Report.PDF [Accessed: $25^{\text {th }}$ June 2018].

Ellen, B. (2015) New President in Sri Lanka puts China's Plans in Check, The New York Times [Online] Available from: https:// www.nytimes.com/2015/01/10/world/asia/new-president-insri-lanka-puts-chinas-plans-in-check.html?rref=collection/ timestopic/Rajapaksa,Mahinda [Accessed: $20^{\text {th }}$ February 2017]. 
Gamage, R. (2017) Balancing and bandwagoning: explaining shifts in Sri Lankan foreign policy, Journal of the Indian Ocean Region, 13(2), pp: 133-154.

DOI: https://doi.org/10.1080/19480881.2017.1299450

Ge, S. (2017) Remarks, In George I. H. Cooke (Ed) Contemporary China-Sri Lanka Relations, pp: 4-6, Borella, Sri Lanka: BCIS Press.

Gjørv, G. (2012) Security by any other name: negative security, positive security, and a multi-actor security approach, Review of International Studies, 38 (4), pp: 835 - 859.

DOI: https://doi.org/10.1017/S0260210511000751

Goldstein, L. (2015) Meeting China Halfway: How to Defuse the Emerging US-China Rivalry, Washington, D. C.: Georgetown University Press.

Indiatoday.in (2015) India's spy agency RAW behind my poll defeat, says former Sri Lankan president Mahinda Rajapaksa, India Today [Online] Available from: https://www.indiatoday. in/world/story/sri-lanka-president-mahinda-rajapaksablames-india-raw-for-his-election-defeat-244216-2015-03-13 [Accessed: 25 ${ }^{\text {th }}$ June 2016].

Jayawardena, A. (2017) Sri Lankan Perspectives of China-Sri Lanka relations: Challenges and Prospects, In George I. H. Cooke (Ed) Contemporary China-Sri Lanka Relations, pp: 13-17, Borella, Sri Lanka: BCIS Press.

Jian, G. and Xiaoqin, D. (2015) The New Silk Road as an Emerging Model of Regional and International Economic Cooperation-A Brief Review of the International Symposium on "The New Silk Road and China-Africa Economic Relations", International Critical Thought, 5(4), pp: 529-532.

DOI: https://doi.org/10.1080/21598282.2015.1102156

Kahandawaarachchi, T. (2017) Why did Sri Lanka seek Chinese investments in ports?, Daily FT [Online] Available from: http:// www.ft.lk/article/634174/Why-did-Sri-Lanka-seek-Chineseinvestments-in-ports [Accessed: $25^{\text {th }}$ June 2018].

Karunanayake, R. (2017) Sri Lanka to pursue "friendship with all, enmity with none", Colombo Gazette [Online] Available from: http://colombogazette.com/2017/06/02/sri-lanka-topursue-friendship-with-all-enmity-with-none/ [Accessed: $25^{\text {th }}$ June 2018].

Keohane, R. and Nye J. (2012) Power and Interdependence, $4^{\text {th }}$ Ed, New York: Longman.

Kissinger, H. (2015) World Order, New York: Penguin Publishers.

Lone, M. (2017) The new great game in south Asia: theorising the geopolitical outfoxing of India, International Journal of Scientific and Research Publications, 7(5), pp: 127-144.

Lukonin, S. (2017) Redefining Russia's Pivot and China's Peripheral Diplomacy, In Lora Saalman (Ed.) China-Russia relations and regional dynamics, pp: 3-6, Stockholm: SIPRI Publication.

Malik, M. (2009) India-China Relations, In Linsun Cheng (Ed.) Berkshire Encyclopedia of China, pp: 1143-1150, Berkshire: Berkshire Publishing Group.

Malik, M. (2017) China and India: The Roots of Hostility, The Diplomat [Online] Available from: https://thediplomat. com/2017/09/china-and-india-the-roots-of-hostility/ [Accessed: 25 ${ }^{\text {th }}$ June 2018].

Mendis, P. (2017) The Past as Prologue in Sino-Sri Lankan Intercourse, Harvard International Review [Online] Available from: http://hir.harvard.edu/article/?a=14563 [Accessed: $23^{\text {rd }}$ June 2018].

Menon, S. (2016) Choices: inside the making of India's Foreign Policy, Gurgaon Haryana: Allen Lane.

Ministry of Defense (2016) India will give its fullest support to Sri Lanka's policies; Assures Indian Foreign Minister, Ministry of Defense Sri Lanka [Online] Available from: http:// www.defence.lk/new.asp? fname=India_will_give_its_fullest support_to_Sri_Lanka_policies_Assures_Indian_Foreign_ Minister_20160207_01 [Accessed: 25 $5^{\text {th }}$ June 2018].

Ministry of Foreign Affairs (2017) Foreign Minister Tilak Marapana calls on Indian Prime Minister Narendra Modi, Ministry of Foreign Affairs Sri Lanka [Online] Available from: https://www.mfa.gov.lk/visit/foreign-minister-tilak-marapanacalls-on-indian-prime-minister-narendra-modi/ [Accessed: $20^{\text {th }}$ June 2018].

Mitra, D. (2017) Despite Security Assurances, Chinese Consolidation of Sri Lankan Ports Remains a Worry for India, The Wire [Online] Available from: https://thewire.in/ diplomacy/hambantota-china-sri-lanka-ports [Accessed: $18^{\text {th }}$ November 2017].

Moramudali, U. (2017) Sri Lanka's Debt and China's Money, The Diplomat [Online] Available from: https://thediplomat. com/2017/08/sri-lankas-debt-and-chinas-money/ [Accessed: $25^{\text {th }}$ June 2018].

Narayan, S. (2017) India-Sri Lanka Economic Relations (Guest Lecture), $20^{\text {th }}$ November, Lakshman Kadirgamar Institute of International Relations and Strategic Studies, Sri Lanka.

Oba, M. (2016) TPP, RCEP and FTAAP: Mulitlayered Regional Economic Integration and International Relations, Asia-Pacific Review, 23(1), pp: 100-114.

DOI: https://doi.org/10.1080/13439006.2016.1195957

Ockersz, L. (2017) Current foreign policy dilemmas of small states: The case of SL., The Island [Online] Available from: http://www.island.lk/index.php?page_cat=articledetails\&page $=$ article-details\&code_title $=165255$ [Accessed: $18^{\text {th }}$ February 2018]. 
Panditaratne, D. (2017) Re-Energising the SAARC Process, Lakshman Kadirgamar Institute [Online] Available from: http://www.lki.lk/events/lkis-dinusha-panditaratne-speaks-reenergising-saarc-process/ [Accessed: 25 ${ }^{\text {th }}$ June 2018].

Pattanaik, S. (2016) Indian Ocean in the emerging geo-strategic context: examining India's relations with its maritime South Asian neighbours, Journal of the Indian Ocean Region, 12(2), pp: 126-142.

DOI: https://doi.org/10.1080/19480881.2016.1226750

Pollack, J. (2005) The transformation of the Asia security order: assessing China's impact, In David Shambaugh (Ed.) Power Shift: China and Asia's new dynamic, pp: 329-346, Los Angeles: University of California Press.

Prime Minister's Office (2017) Vision 2025, Colombo: Prime Minister's Office [Online] Available from: http://www. pmoffice.gov.1k/download/press/D00000000061_EN.pdf [Accessed: 22 ${ }^{\text {nd }}$ March 2018].

Rajapakse, G. (2014) Sri Lanka's National Security, PRISM, 4(4), pp: 139-155.

Reuters (2017) Sri Lanka PM courts increased infrastructure investment from China, Reuters [Online] Available from: https://www.reuters.com/article/china-sri-lanka/sri-lankapm-courts-increased-infrastructure-investment-from-chinaxinhua-idUSL4N1II406 [Accessed: $20^{\text {th }}$ February 2018].

Rizvi, A. [2015] The Downfall of the King: A Victory for Democracy in Sri Lanka, Harvard International Review [Online] Available from: http://hir.harvard.edu/article/?a=9876 [Accessed: 25 ${ }^{\text {th }}$ June 2018].

Samaranayake, N. (2012) The Long Littoral Project: Bay of Bengal- A Maritime Perspective on Indo-Pacific Security, Centre for Naval Analysis [Online] Available from: https:// www.cna.org/cna_files/pdf/IRP-2012-U-002319-Final.pdf [Accessed: $25^{\text {th }}$ January 2017 ].

Samaraweera, M. (2017) Sri Lanka's Peace and Reconciliation Process, News.lk. [Online] Available from: https://www.news. $1 \mathrm{k} /$ fetures/item/15646-sri-lanka-s-peace-and-reconciliationprocess [Accessed: $25^{\text {th }}$ June 2018].

Senadhira, S. (2017) New trio to handle middle-path foreign policy, friendship with all, Ceylon Today [Online] Available from: http://www.ceylontoday.lk/print20170401CT20170630. php?id=28162 [Accessed: $25^{\text {th }}$ June 2018].

Shimbun, Y. (2018) Japan to offer aid for Indian Ocean ports, The Japan Times [Online] Available from: http://the-japannews.com/news/article/0004465715?m=jnnl [Accessed: 25 ${ }^{\text {th }}$ June 2018].

Singh, A. (2015) China's 'Maritime Bases' in the IOR: A Chronicle of Dominance Foretold, Strategic Analysis, 39(3), pp: 293-297.

DOI: https://doi.org/10.1080/09700161.2015.1022320
Sirisena, M. (2015a) Policy Statement delivered by President Maithripala Sirisena addressing the $8^{\text {th }}$ Parliament of SriLanka on September 1, 2015, Presidential Secretariat Sri Lanka [Online] Available from:http:/www.president.gov.lk/policy-statementdelivered-by-president-maithripala-sirisena-addressing-the8th-parliament-of-sri-lanka-on-september-1-2015/ [Accessed: $25^{\text {th }}$ June 2018].

Sirisena, M. (2015b) Maithripala Sirisena Manifesto, Asian Mirror [Online] Available from: http://www.asianmirror.lk/ news/item/5782-full-text-of-maithripala-sirisena-s-electionmanifesto [Accessed: 25 th June 2018].

Sirisena, M. (2016) Collective endorsement of middle path foreign policy, Presidential Secretariat Sri Lanka [Online] Available from: http://www.presidentsoffice.gov.lk/?p=3566 [Accessed: 25 $5^{\text {th }}$ June 2018].

Smith, C. (2015) What's next for Sri Lanka?, World Economic Forum [Online] Available from: https:/www.weforum.org/ agenda/2015/01/whats-next-for-sri-lanka/ [Accessed: $16^{\text {th }}$ September 2017].

Sultana, G. (2016) Sri Lanka after Rajapaksa: Can it Ignore China?, Strategic Analysis, 40(4), pp: 245-254.

DOI: https://doi.org/10.1080/09700161.2016.1184797

Sundarji, P. (2015) We Can't Have a President with Unlimited Powers: Wickremesinghe, Hindustan Times [Online] Available from:https:/www.hindustantimes.com/world/we-can-t-havea-president-with-unlimited-powers-wickremesinghe/storyOrIrWq8pSngEV9sUrlhJ1M.html [Accessed: 24 ${ }^{\text {th }}$ June 2017].

Sunil, W. A. and Vasantha, D. (2013) Sri Lankan Buddhist extremists attack Muslim-owned businesses, World Socialist Web Site [Online] Available from: https://www.wsws.org/en/ articles/2013/04/02/sril-a02.html [Accessed: $25^{\text {th }}$ June 2018].

Uyangoda, J. (2016) Taking Sri Lankan Foreign Policy to the Post-Confrontational Phase, The Wire [Online] Available from: https://hewire.in/world/taking-sri-lankan-foreign-policy-tothe-post-confrontational-phase [Accessed: 22 ${ }^{\text {nd }}$ December 2016].

Vandewalle, L. (2016) India and China: too close for comfort?, Brussels: European Parliament [Online] Available from: http:// www.europarl.europa.eu/RegData/etudes/IDAN/2016/570466/ EXPO_IDA(2016)570466_EN.pdf [Accessed: 27 $7^{\text {th }}$ March 2017].

Wagner, C. (2016) The Role of India and China in South Asia, Strategic Analysis, 40(4), pp: 307-320.

DOI: https://doi.org/10.1080/09700161.2016.1184790

Walt, S. (1990) The Origin of Alliance, Ithaca: Cornell University Press.

Waltz, K. (2000) Structural Realism after the cold war, International Security, 25(1), pp: 5-41.

DOI: https://doi.org/10.1162/016228800560372 
Wang, V. (2011) "Chindia" or Rivalry? Rising China, Rising India, and Contending Perspectives on India-China Relations, Asian Perspective, 35(3), pp: $437-469$.

Wee, S. and Neogy A. (2010) Wen says world big enough for India and China growth, Reuters [Online] Available from: http://www.reuters.com/article/us-india-chinaidUSTRE6BE1BM20101215 [Accessed 19 ${ }^{\text {th }}$ May 2016].

Wickremesinghe, R. (2017) Economic Policy Statement [Online] Available from: http://www.pmoffice.gov.lk/ download/press/D00000000062_EN.pdf?p=7 [Accessed: 25 $5^{\text {th }}$ June 2018].
Wijeyarathna, N. (2017) Takeaways - Dr. Ranee Jayamaha on the Belt and Road Initiative and Potential Economic Benefits to Sri Lanka, The LKI [Online] Available from: http://www.lki.lk/ publication/dr-ranee-jayamaha-on-the-belt-and-road-initiativeand-potential-economic-benefits-to-sri-lanka/ [Accessed: $27^{\text {th }}$ June 2018].

World Bank (2017) SRI LANKA DEVELOPMENT UPDATE: Creating opportunities and managing risks for sustained growth [Online] Available from: http://documents.worldbank.org/ curated/en/955451509391414963/pdf/120728-REVISED-SriLanka-Development-Update-November-2017-final-31102017. pdf [Accessed: 28 ${ }^{\text {th }}$ June 2018]. 